\title{
HAS THE COVID 19 PANDEMIC AFFECTED THE WORLD EQUALLY?
}

\author{
Ljiljana Stošić Mihajlović1 ${ }^{\text {, Svetlana Trajković }}{ }^{2}$ \\ ${ }^{1,2}$ Academy of Technical and Educational Vocational Studies in Nis \\ ljiljana.stosic.mihajlovic@ akademijanis.edu.rs, svetlana.trajkovic@akademijanis.edu.rs
}

\begin{abstract}
Rich and powerful people have built a new system in which only risk is common, and profit is exclusively theirs. Neoliberalism is an ideology that is realized in the interest of the rich and powerful. They have enormous financial (and not only financial) power by which they shape the political, media and (quasi) scientific space in order to conduct economic policy and publicly promote the values that suit them. That is why in recent years we have mostly heard that the problem has arisen because people do not live in accordance with the real possibilities and that we must continue to tighten our belts and rationalize our jobs (translated from Orwell's new speech: further dismissals of employees). Much less is said about the problem of inequality, i.e. uneven and unjust distribution and concentration of wealth, and that a solution should be sought there. The latest economic crisis caused by COVID / 19 has shown that not everyone is equally affected by the crisis: the rich have become even richer and the poor have become even poorer. This paper will discuss the unequal consequences caused by the latest pandemic crisis.
\end{abstract}

Keywords: pandemic, inequality, economy, markets, business systems

\section{INTRODUCTION}

The COVID-19 pandemic has introduced an unprecedented amount of uncertainty into the global economy as countries around the world battle growing troubles, implement broad social distancing
Professional Paper

10.5937/jouproman9-31417

strategies, and seek fiscal interventions to stabilize markets.

The rich and powerful have built a system in which the risk is common, but the profit is only theirs, where huge private gains are made on the basis of public loss, i.e. profit is privatized by a small number of powerful and rich, and losses are socialized - transferred to the weak class and the poor. Thus, we have now come to the paradoxical situation that people in the 21 st century in almost all countries of the world (despite unprecedented technological progress and productivity growth) work more and more time for less and less money, and that in most countries, even in those economically most developed, they have been realistically reducing salaries and pensions for years, and the new, modern generations are living worse than their parents.

Society is rapidly stratifying into a dwindling number of the extremely rich and a huge number of the poor, with a rapid thinning of the middle class. If this trend continues, there is a danger that $99 \%$ of the population will become a "postmodern service for the $1 \%$ of the richest"[1] 


\section{STATE MEASURES TO ASSIST VULNERABLE CATEGORIES IN THE FIGHT AGAINST VIRUSES IN SERBIA}

Serbia, as a country with an accelerated rate of development, was severely affected by the COVID-19 pandemic, in the sense that the initiated development cycle had to be briefly interrupted. But, thanks to measures to support the economy and citizens, Serbia has managed to find itself at the very top of European countries that have successfully confronted the crisis caused by the pandemic.

In the first package of measures to help the economy in the middle, in 2020, there were several different types of support. When it comes to tax policy, deferral of taxes and contributions for employees and advance payment of income tax for 2020 are defined. Businessmen could defer tax liabilities until January 4, 2021, which means that at the beginning of the year, these debts were due. The company will be able to settle its tax liabilities in 24 equal monthly installments without interest.

Business entities - legal entities, including branches and representative offices of foreign legal entities, could postpone the advance payment of corporate income tax for March, April, and May 2020, until the submission of the final corporate income tax return for 2020. When it comes to direct assistance to companies in the form of payment of 3 minimums, i.e. nonrefundable funds from the budget in the amount of about 30,000 dinars per employee, entrepreneurs and legal entities classified as micro, small and medium were entitled to them. After the first three months (April, May and June), the state extended this type of support for another two months, when companies were paid $60 \%$ of the minimum for each employee.

These payments were made from funds that Serbia borrowed from foreign investors.

After three packages of aid to the economy, which cost the budget a little more than eight billion euros, Serbia is approaching the limit of public debt of $60 \%$.

But it is almost forgotten that Serbian legislation provides for a lower level of public debt. According to the Law on Budget System, public debt cannot exceed $45 \%$ of GDP, but that level of debt, according to the then calculation of GDP, Serbia broke through in October 2011, just a few months after this fiscal rule entered into law. So, for almost 10 years, Serbia has been in legal violation, when it comes to public debt. However, Olivier Blanchard said that the world is too complicated for us to reduce it to simple rules. And that is why these arithmetic limits are illusions. It is much more important than them whether the debt is sustainable. That is, at what interest rate do the countries borrow, what is the economic growth, as well as what is the deficit in the budget. And more importantly - how much is the deficit in the state treasury, less interest costs. This is what economists call the primary deficit.

\section{THE GREED OF THE RICH GROWS DURING THE GLOBAL CRISIS}

For years, top managers of large financial firms received astronomical bonuses and salaries, and when the global financial crisis hit, these firms (which, to a large extent, sponsored the crisis) found themselves on the brink of bankruptcy and the US authorities spent to save them. 
Thousands of billions of dollars, and after that they will continue to work according to the old system - continuing to engage in increasingly risky machinations and paying themselves huge salaries and bonuses. [2]

Even in times of global crisis, the greed of the rich is growing. The state pumps huge funds to save private companies by socializing their losses, and they use those funds to, above all, increase profits through speculative operations, which they privatize through the payment of huge bonuses and dividends. The intensity of falling wages and profit growth has especially increased since the 1980s, and just at the time of the current crisis it is reaching its historical minimums (salaries), as well as maximums (profit).

The following example The United States and most other countries, in order to prevent financial and economic collapse, came to the aid of troubled private companies by providing them with huge financial infusions. As a result, states borrowed and increased their public debt. Thus, the losses of the private sector are transferred to the back of the state and the problem is moved from one part of the economy to another - from private to state debts. When the problem shifted from private to public debt, the neoliberals became loud again and aggressively preached their famous dogmas again. They claim that the problem is always and only in the state and public spending, and never in the private sector and private spending. Therefore, private sector spending should not be controlled and limited, because the private sector always behaves rationally - it borrows, invests and spends reasonably, and control of public (state) spending, i.e. public debt is a prerequisite for a successful economic policy that protects the country from crisis.

The COVID-19 pandemic has disrupted the world-class economy, on a scale and scale not seen since World War II. At the same time, although the pandemic has been going on for more than a whole year, the economic recovery by the end of 2020 is very modest and completely uneven.

According to the International Labor Organization's February 2021 report on the economic consequences of the pandemic crisis, young workers, women, the selfemployed, and low- and middle-skilled workers were most affected. [3]

Approximately 114 million people in the world lost their jobs due to the COVID-19 pandemic, but also anti-pandemic measures, locks and restrictions imposed by mostly all countries and, consequently, large companies. The worst affected are young workers, followed by employed women, the self-employed and low- and medium-skilled workers. Predictions are that in 2021, the world will continue to face a business crisis, as well as strong uncertainty and uncertainty of economic recovery. Analyzes of indicators on the state of the world economy have shown that the largest losses in terms of job losses were recorded in the United States, and the lowest in Central Asia, as in Europe, given that in these regions the most active economic measures were implemented by the state leadership. Related to the preservation of jobs, through the reduction of working hours with financial support primarily to the SME sector and employees. 
The analyzes of the World Labor Organization were compiled on the basis of information from different countries, which show that the measures of financial support to employees significantly mitigated the impact of the crisis, however, the data showed that financial support was uneven in different countries and in different economic sectors. The result of the research is that in the general case, young workers, women, the self-employed and low and medium skilled workers are the most severely affected. In relative terms, the largest job loss is in women $(5 \%)$ as opposed to men, as well as in younger workers $(8.7 \%)$ compared to older workers.

In addition, the latest ILO estimates are that during 2020, due to a pandemic in the world economy, about $9 \%$ of total working time was lost, compared to the last quarter of 2019, which is equivalent to the loss of 255 million full-time jobs. The largest losses of working time in the world economy during 2020 were realized in the second quarter (more than 18\%), which is equal to the amount of 525 million fulltime jobs, with 48 hours of work per week. Also, according to an available ILO report, in 2020 there was a decline in total labor income, excluding measures of state financial support, of $8.3 \%$, or 3.7 thousand billion dollars, or more than $4 \%$ of global gross product. ILO analysis shows that during the second wave of the pandemic, the situation improved, so that in the third quarter of 2020, there was a decrease in the loss of working time of $7 \%$ compared to $12 \%$ in the first half of 2020. According to the available data, the increase in working hours was especially noticed in countries with lower incomes, including Serbia.
All economies in the countries of the world are affected by the global pandemic. Thus, economists in Great Britain believe that this country has experienced the largest decline in economic activity since 1709 , that is. The British economy has suffered the deepest annual decline since the socalled Great Frost in 1709, published by the Bureau of National Statistics. Namely, the British Bureau of National Statistics announced that early estimates, subject to revision, showed that the gross domestic product (GDP) fell by 9.9 percent in 2020.[4]

Economists believe that this is a consequence of the "hibernation" of a large part of the economy due to the locks and restrictions that were introduced in order to prevent the spread of the corona virus. The biggest decline was recorded in April, May and June, i.e. in the second quarter of 2020, as a consequence of the initial locking of the country. Also, according to British economists, the so-called a double recession that is expected at the end of 2020 , so that in the quarter OctoberDecember 2020, a growth of $1 \%$ was reported, which is better than expected.

The consequence of the imposed state of emergency is the loss of jobs for more than 800,000 people since the beginning of the pandemic. Measures to combat the economic crisis and protect jobs and the functioning of companies show that the British Treasury has taken the biggest step in borrowing, through a program that exceeds 400 billion pounds in this business year.

In Serbia, due to a pandemic caused by the corona virus, more than 2,000 people lost their jobs in tourism, or about $60 \%$ of people from travel and car rental agencies lost their jobs. 
Before the pandemic, about 4,000 people worked in tourism, travel agencies and car rental companies, and by January 2021, about $45 \%$ of them had lost their jobs. An additional number of people lost their jobs after the expiration of the obligation of employers who took the help of the Government of Serbia not to lay off employees. As a reminder, domestic travel agencies that organized tourist trips, before the crisis, had a turnover of $1-1.5$ billion euros a year. Last 2020, the turnover amounted to 150 million euros, which means that more than a billion euros of turnover was lost. On the other hand, the agencies themselves were at a loss of 120150 million euros, which is a big loss for our country.

When it comes to domestic tourism, receptive tourism in Serbia was expanding before the corona virus and generated foreign exchange income of 1.2 billion during the year.

According to the data of the Agency for Business Registers, as of March 15, 2020, 94 tourist agencies have been deleted, while 105 other business entities in the field of tourism have stopped working, and that number is expected to increase. It is important to note that travel agencies are often small businesses that are an important source of income for many families.[5]

Their survival is also important because replacement travel and refunds to travelers depend on the survival of agencies and that is why it is important for travel agencies to receive grants to preserve their business. Therefore, the real question is why the state still avoids helping those who record losses of more than $90 \%$, and on whom the return of money to the citizens of Serbia who paid for travel before the crisis depends. Also, according to the data of the Business Registers Agency, as of March 15, 2020, 94 agencies have been deleted, of which 20 travel organizers, while 105 business entities, including 10 travel organizers, have stopped working. It is to be expected that the problems will increase during February and March, when the payment of deferred taxes and contributions arrives, which, in reality, the agencies cannot pay, because they have not been operating for a year.

One way to help the hardest hit sector is: to write off debt; to grant one-time assistance to other vulnerable categories; to speed up the approval of loans from the Development Fund. The model might be similar to a set of measures the state has used to help city hotels and subsidies for carriers, given that their business is also at stake. SMEs from vulnerable sectors, such as tourism, logistics and services in general, certainly expect their arguments based on balance sheet loss indicators to be taken into account.

And as if the impact of the pandemic on poor business results is not enough, many specific travel agencies have objections to the law, which prescribes obtaining licenses to do business, because they need expensive bank guarantees, which most could not provide.

The total wealth of the ten richest people increased by 540 billion dollars during the pandemic and now amounts to 11.95 trillion. 
Picture 1.[OC] Net worth comparison of the top 10 richest person in the world in March 2020 and January 2021

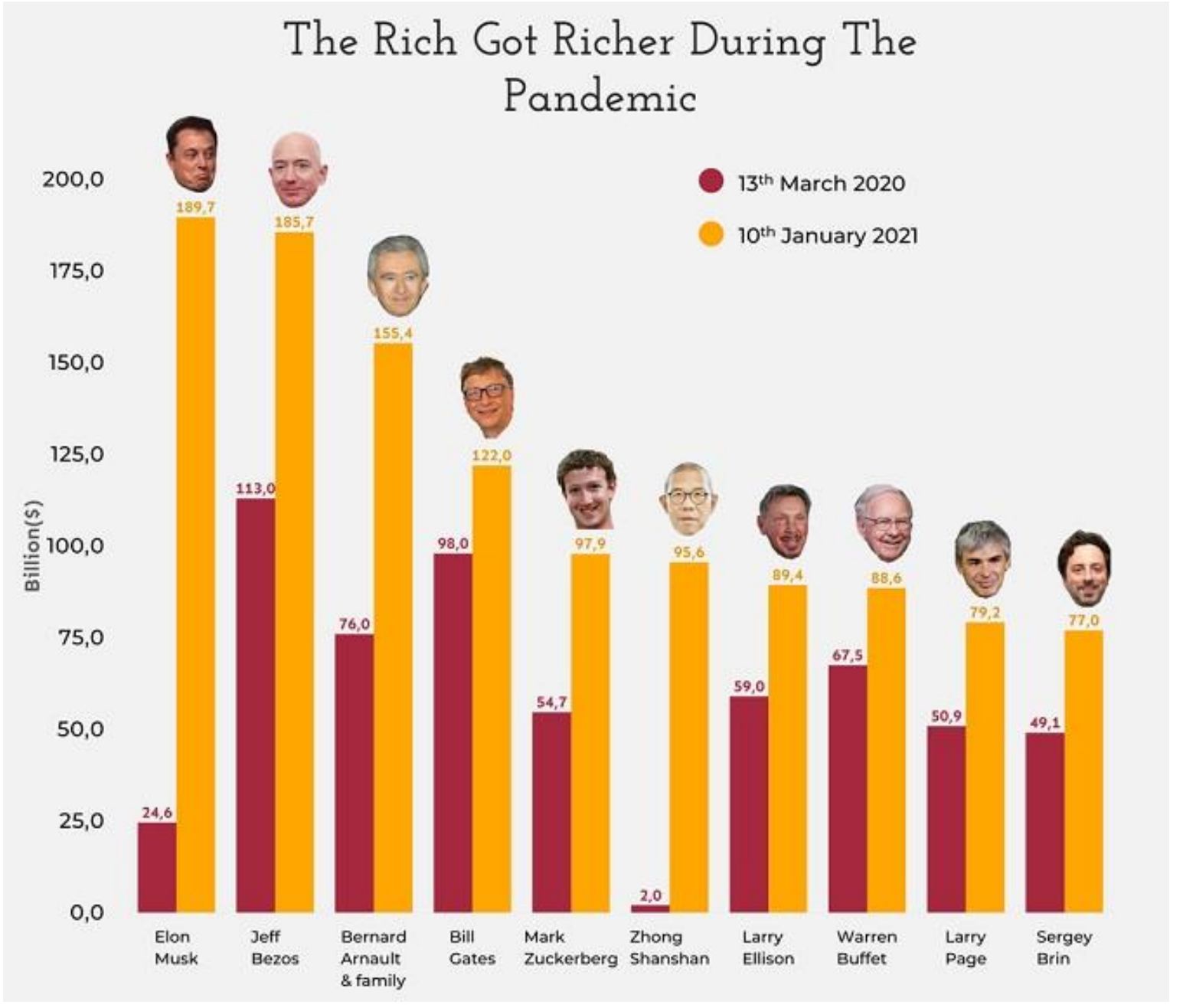

Source:i.redd.it/5wk7wh09bhb61.png

While workers around the world lost their jobs and incomes during the COVID-19 pandemic, the total wealth of the ten richest people increased by 540 billion dollars, so that it now amounts to 11.95 trillion. That amount is enough to buy a vaccine for every individual on the planet and to prevent anyone from being poor and on the brink of subsistence due to the crisis, the international humanitarian organization Oxfam states in its report "Inequality Virus".

Collectively, the wealth of Jeff Bezos, Mark Zuckerberg, Elon Musk and seven other billionaires from the Forbes list of the ten richest, is equal to the total spending of all G-20 members to recover from the pandemic. The general conclusion is that the rich benefited the most from state aid. When the virus reached the United States and Europe last spring, global markets experienced a decline, followed by locking measures. However, the markets recovered quickly, primarily thanks to previously unrecorded monetary and fiscal measures taken by all governments and central banks of the countries, in order to mitigate the consequences of the crisis. 
Research has shown that the pandemic has hit women, younger workers and ethnic minorities the hardest. For them, the highest probability is: that they will become impoverished; that they will be hungry; that he will be left without health care. For people who lived hard before COVID-19, it is quite certain that the recovery will be difficult and long. According to estimates, it will take the next ten or more years for workers to recover from the economic consequences of the pandemic due to the virus.

2020 is the year of the pandemic. It has irreversibly set back the development in the eradication of misery and poverty throughout the world, which has been achieved over the past decades. According to Oxfam estimates, between 200 and 500 million people are now even more impoverished at the time of the pandemic. For example, at the beginning of the pandemic, in poor countries at least $1 / 2$ of the workers lived in misery and poverty, and even $3 / 4$ workers in the world were not entitled to sick leave or unemployment benefits.

In the same period, Amazon owner Jeff Bezos earned so much between March and September 2020 that he could give each of the 876,000 employees a $\$ 105,000$ bonus, and still have as much money as he had before. the onset of a pandemic.

In that sense, Oxfam proposed that radical measures be taken towards a more just society. These measures relate to an increase in corporate taxes and an increase in the property tax rate. These proposals are already opposed by the business community, citing arguments that it creates both jobs and income.

According to free market economy, director of the British Institute of
Economics: "A higher tax on the rich sounds good as a newspaper headline, but it deceives the public who might think that cuts at the top automatically bring more money to those at the bottom. The reality is that such interventionist measures are more likely to destroy wealth than to share it more fairly."

And the calculation is simple: if a temporary tax on extra profit had been introduced last year alone, the 32 global corporations that profited the most would have had to collect $\$ 104$ billion. This amount is sufficient: for unemployment benefits, to help children and the elderly in low- and middle-income countries; to support the health system in underdeveloped countries.

Many rich people would surely point out that they already give enough anyway. It is true that since the beginning of the pandemic, celebrities, athletes and businessmen have been making extraordinary donations. According to the data of the USB bank, 209 billionaires set aside 7.2 billion dollars from March to June last year to fight COVID-19. At the beginning of the year, it was announced that Jeff Bezos' ex-wife gave more than four billion dollars to public kitchens and emergency aid funds in four months. Bezos donated 125 million in June to fight the virus, which is certainly a lot of money.

Particularly generous in providing financial assistance to the most vulnerable people due to COVID-19, was the cofounder of "Twitter" Jack Dorsey, who in June 2020 alone paid a billion dollars into the fund for assistance due to the pandemic, which is more than 1/4 of their total, estimated wealth, which is also significant, but does not diminish the fact that the rich earned much more in the pandemic. 
Also, the Bill and Melinda Gates Foundation paid 1.75 billion as a global response to COVID-19. This money is intended for the development and distribution of vaccines and tests. It should be noted that the Bill and Melinda Gates Foundation is the third largest amount of donations paid to the World Health Organization.

At the beginning of the Vet economic forum in Davos, which was held online for the first time this year, Oxfam published a report on that. World Health Organization Director-General T. Gebrejesus said the world was on the brink of "catastrophic moral defeat" because rich countries had reserved most of the available vaccines for themselves. ${ }^{1}$

\section{THE IMPACT OF THE PANDEMIC ON CONSUMER HABITS}

The world economy will certainly never be the same as before the COVID-19 pandemic. Once all this is over, once the economy recovers, it will be difficult to return to the level before the pandemic. At the start of the pandemic, economists expected the economy to recover likely in the third quarter of 2020. However, this expectation turned out to be unrealistic and ambitious, because the scale of the crisis was not fully understood. However, economists from Morgan Stanley pointed out that: "Evidence suggests that the virus / economy equation has shifted decisively since the early days of the outbreak," in a note to clients, adding that the recovery continued to gain momentum as countries became better at managing the virus.
U.S. economists see a faster return to preCOVIDA-19 production levels, believing the U.S. economy could reach pre-COVID19 levels by the second quarter of 2021, while entire developed markets could reach that level by the third quarter of 2021. The outlook for the impact of Covid-19 on the economy has changed dramatically, with most large economies capable of raising economic activity to much higher levels despite the constant spread of the virus. The medical community continues to make good progress in the fight against Covid19, and treatments and vaccines are available in the next few months.

Thus, the increase in total turnover amounted to 38 billion dollars. By mail and the Internet alone, total turnover increased by $\$ 176$ billion.

In modern conditions, which some analysts compare with the twilight of Western civilization, it can be said that the life motto of modern, Western man is: "I spend, so I live." At the same time, the greatest pleasure of modern man is when he is "nailed" to the TV, internet and mobile phone.

In addition, locks, curfews, and movement bans have helped to increase changes in consumption, changing humanity's daily, ordinary lives. Truth be told, some were happy with these changes, some were not happy and even fell into a state of stress and additional depression, because there was a huge jump in the number of unemployed in the US, with the first affected SMEs and labor-intensive sectors are also most affected by movement bans and work bans.

\footnotetext{
${ }^{1}$ Kavaja, J. Stanje stvari, Politia, 29.01.2021.
} 
For example, in December 2020 alone, retail sales in the United States decreased by $0.7 \%$, compared to November 2020 , while it increased by $2.9 \%$ compared to December 2019.

The biggest changes in 2020 compared to 2019 in the US consumption sector are as follows:

1. Retail trade (excluding stores), such as mail order and internet purchases, increased by $22.1 \%$, and increased by $0.6 \%$ in total. In absolute terms, the growth of total turnover amounted to 38 billion dollars, by mail and the Internet it increased by 176 billion, so that after its deduction it decreased by 138 billion dollars, or $2.6 \%$. The share of purchases via mail and the Internet increased from $12.8 \%$ in 2019 to $15.5 \%$ in 2020 . According to all indicators, this share is likely to continue to increase in 2021, because it is a long-term process.

2. In terms of sectors, consumption in restaurants and salons (drinking places) decreased the most (by as much as 149 billion dollars). In percentage or relative terms, the decrease was close to $1 / 5$ or $20 \%$. However, the decline in consumption in restaurants was affected by the increase in consumption in food and beverage stores by 88 billion, which is $11.5 \%$.

3. Fuel consumption at gas stations has been reduced by 80 billion dollars (due to locking and movement bans, but also due to lower fuel prices). The reduced value of turnover as a percentage is $15.9 \%$.

4. Nevertheless, the largest relative decrease in the value of turnover was recorded by specialized clothing and footwear stores by as much as $26.4 \%$. Americans "saved" 70.5 billion dollars on clothes in 2020
5. Lower spending on travel and clothing was offset by purchases of construction materials and garden equipment, and these expenditures increased by $14 \%$ or $\$ 54$ billion.

6. Although lower consumption was recorded at gas stations, consumption for purchases of cars and auto parts increased, in line with the increase in the number of adults who reached adulthood by $1.1 \%$, or in absolute terms by 13.6 billion dollars.

7. Increased spending on car purchases appears to have led to savings on purchases of electronic products and equipment, down $\$ 14.2$ billion, or $14.6 \%$.

8. In public bans and artificially created free time, Americans have also increased spending in: specialized sports equipment stores, hobby stores, musical instruments, and bookstores. As a percentage, growth was $5.7 \%$ or in absolute terms $\$ 4.6$ billion.

9. It seems that the smallest increase in spending on the purchase of medicines and maintaining health is unexpected, because for these purposes purchases increased by less than $2 \%(1.7 \%)$ or by 6.1 billion dollars in specialized stores and pharmacies for the purchase of medicines and cosmetics.

According to analysts: These changes are in line with the philosophy of Karl Marx, "alienation of man from man." This process has been going on since the industrial revolution, for more than 200 years, but in 2020 it reached unprecedented proportions, and the most intensive changes, not counting the war years. ${ }^{2}$

\footnotetext{
${ }^{2}$ Zdravković, M: Uticaj pandemije na ponašanje i potrošnju Amerikanaca u 2020. by stanje stvari on 19. januara 2021.
} 


\section{CONCLUSION}

The COVID-19 virus pandemic hit the whole world exactly a year ago, but despite drastic and unprecedented "locking" measures, followed by a race to find a vaccine and large expenditures of all countries in the world to protect the economy - the crisis continues. The worst thing is that all the forecasts regarding how long the crisis will last, simply fall into the water that is. No one still knows how long the crisis will last, because the strains of the virus are changing rapidly, medicine is not able to find an effective cure, and health systems are slowly collapsing under the weight of the situation. However, it seems that the crisis has not hit the world equally: the richest have become even richer; the poor were further impoverished. In any case, people's consumption habits have changed significantly compared to the pre-crisis situation. This is best illustrated by the data on the state of consumption in the United States in relation to 20189. Similar results and comparisons can be obtained for other countries in the world. However, not everything is so simple. There are also those who were rich even before the crisis, they became even richer during the crisis, but they also donated significant funds, primarily to virus vaccine research programs.

\section{REFERENCES}

[1] Dušanić, J., (2020). Ekonomsko troknjižje, knjiga prva: Ekonomija postmoderne $i$ neoliberalizam, izdanje IP Filip Višnjić, Beograd.

[2]Mason, P., (2017). Post Capitalism: A Guide to Our Future, Farrar, Straus i Giroux.

[3] Kavaja, J. Stanje stvari, Politia, 29.01.2021.

[4] Office for National Statistics www.ons.gov.uk/economy/grossdomestic

[5] Report of the International Labor Organization from February 2021

[6] Stošić Mihajlović, Lj., Trajković S., (2020). The importance of logistics and supply chains for pandemia conditions, (JPMNT) Journal of Process Management - New Technologies, International Vol. 8, No 2, pp.53-59

[7] Zdravković, M: Uticaj pandemije na ponašanje i potrošnju Amerikanaca u 2020. by stanje stvari on 19. januara 2021.

[8] www.cbsnews.com/news/transcript-olivierblanchard-speaks-with-michael-morell-onintelligence-matters/

[9]www.census.gov/retail/mrts/covid19

[10]https://www.morganstanley.com/ideas/thoughts

[11]https://www.oxfam.org/en/5-ways-women-andgirls-have-been-hardest-hit-covid-19

[12]https://inequality.org/great-divide/updatesbillionaire-pandemic/

[13] https://i.redd.it/5wk7wh09bhb61.png 